\title{
Literatura hipertekstowa a preferencje czytelnicze młodzieży (implikacje dydaktyczne)
}

\section{Hypertext literature and young people's reading preferences (Didactic implications)}

\author{
Beata Jarosz \\ Uniwersytet Marii Curie-Skłodowskiej w Lublinie
}

\begin{abstract}
In the article hypertext literature is presented in the context of the reading preference of young people and the deepening crisis of readership. The author justifies the value of e-literature in developing the reading interests of contemporary young people, demonstrating that digital works thanks to broken linearity, multilevel architecture, multimediality, and the combination of static and kinetic typography, digital works, guarantees a special kind of literary and entertainment feast combined with intellectual and creative inspiration. On the one hand, the recipient assorts with the attractive hybrid structure and has the possibility of reading based on making one's own choices; on the other - the reader could still continue to develop reading comprehension skills, aesthetic sensitivity, emotional and rational intelligence, imagination, as well as a variety of other skills: interpretative, argumentative, analytic etc.
\end{abstract}

Key words: hypertext literature, readership, reading preferences

Streszczenie: W artykule zaprezentowano literaturę hipertekstową w kontekście preferencji czytelniczych młodych ludzi i pogłębiającego się kryzysu czytelnictwa. Autorka uzasadnia wartość e-utworów w rozwijaniu zainteresowań czytelniczych współczesnej młodzieży, wykazując, że dzieła cyfrowe dzięki przełamanej linearności, wielopiętrowej architekturze, multimedialności, zespoleniu typografii statycznej z kinetyczną gwarantują swoistą literacko-rozrywkową ucztę, a przy tym intelektualno-twórczą inspirację. Odbiorca z jednej strony obcuje z atrakcyjną hybrydalną strukturą i otrzymuje możliwość lektury opartej na dokonywaniu samodzielnych wyborów, a z drugiej - wciąż może rozwijać zdolność czytania ze zrozumieniem, wrażliwość estetyczną, inteligencję emocjonalną i racjonalną, wyobraźnię, a także inne różnorakie umiejętności: interpretacyjne, argumentacyjne, analityczne itd.

Słowa kluczowe: literatura hipertekstowa, czytelnictwo, preferencje czytelnicze 
Czytanie jest to odnajdywanie własnych bogactw i własnych możliwości przy pomocy cudzych słów. Jarosław Iwaszkiewicz

Jednym z problemów współczesnego społeczeństwa jest kryzys czytelnictwa, z którym boryka się wiele krajów na świecie, w tym Polska - wypadająca $\mathrm{w}$ rankingach stosunkowo słabo na tle innych państw (Osiecka-Chojnacka 2014). Najbardziej niepokojące są raporty dotyczące dzieci i młodzieży, opracowane w ciągu kilku ostatnich lat. Badania wykazują, że apogeum niechęci do literatury pięknej przypada na okres nauki szkolnej, co może świadczyć o niefunkcjonalności zaleceń ministerialnych zawartych w podstawach programowych z 2008 i 2017 roku. Pomimo iż ustawodawca już dekadę temu umożliwił polonistom elastyczne konstruowanie listy lektur z uwzględnieniem preferencji uczniów, raport z 2016 roku dowodzi, że 29\% młodzieży w wieku 15-19 lat nie przeczytało w 2015 roku ani jednej książki (Michalak, Koryś, Kopeć 2016). Oznacza to, że dziecięca inicjacja literacka (Papuzińska 1981) nie doprowadziła do wykształcenia indywidualnej potrzeby obcowania $\mathrm{z}$ literaturą. Tę formę uczestnictwa w kulturze i spędzania wolnego czasu nastolatek często postrzega w kategoriach przymusu instytucjonalnego (Wolff 2008), kojarząc ją z wysiłkiem, pracą i obowiązkiem. Coraz mniej młodych ludzi uświadamia sobie korzyści płynące z czytania, obca jest im „przyjemność zatopienia się w lekturze, dyskutowania o niej, opowiadania o swoich wrażeniach" (Janus-Sitarz 2009, 105). Oczywiście takiej sytuacji nie jest winna wyłącznie szkoła. Składa się na to wiele czynników, jednak nawet jeśli środowisko rodzinne i rówieśnicze pozostaje poza kulturą pisma, nie oznacza to, że nauczyciel (nie tylko) polonista nie może wpłynąć na zmianę optyki i przyzwyczajeń młodego człowieka.

Od kilku dekad obserwujemy przemiany tradycyjnego paradygmatu kultury stojącej pod znakiem dominacji druku, którą zastępują nowe modele oparte na multimedialności (Gajda 2000), co napawa obawami i generuje zapowiedź śmierci książki. O ile jednak literatura rzeczywiście ulega dostrzegalnym przeobrażeniom, o tyle niepokój o zmierzch czytelnictwa $\mathrm{w}$ efekcie rozwoju cyfrowych technologii jest raczej nieuzasadniony. Pisarze wciąż tworzą, książki wciąż powstają, a jedynie i piszący, i ich dzieła coraz częściej funkcjonują w cyberprzestrzeni, która jest młodemu człowiekowi zdecydowanie bliższa niż świat kartek zszytych z tekturową okładką. 96\% młodzieży w wieku 15-19 lat regularnie korzysta przecież z sieci, odwiedzając portale społecznościowe, szukając informacji, oglądając filmy, słuchając muzyki, czytając blogi itd. 17\% polskiego społeczeństwa czytuje również w Internecie utwory literackie (Michalak, Koryś, Kopeć 2016), choć nie wiadomo, czy deklarujący ów fakt respondenci mieli na myśli zdigitalizowane teksty tradycyjne, czy literaturę hipertekstową oferującą e-czytelnikom ciekawą opowieść w nowoczesnej, 
niepapierowej formie ${ }^{1}$. W środowisku internetowym od niemal dwóch dekad powstają utwory wykorzystujące najnowsze zdobycze techniki i cechujące się nielinearnością, wielowarstwowością, interaktywnością, multimodalnością (np. Szczęsna 2009), które w przypadku próby przekształcenia ich w tradycyjną formę papierową „stracił[y]by wiele - jeśli nie wszystko" (Marecki 2002, 6). Te hipertekstowe opowieści skonstruowane w środowisku cyfrowym (digital born) (Pawlicka 2014a, 149; por. Hayles 2007), wtłoczone w ramy przeglądarki internetowej i przypominające różnorodny semiotycznie portal stanowią często dla współczesnej młodzieży nieznany składnik kultury (e-kultury), a mogłyby one prawdziwie zainteresować przedstawicieli netgeneracji. Co więcej, literaturę sieci wypada postrzegać w kategoriach wartościowego narzędzia modelowania zainteresowań czytelniczych oraz różnorodnych umiejętności, co postaram się wykazać $\mathrm{w}$ niniejszym artykule. Sformułowane tu tezy dotyczące e-literatury stanowią wypadkową dyskusji z polonistami, studentami i licealistami, własnych doświadczeń i obserwacji oraz wniosków obecnych w opracowaniach naukowych i raportach dotyczących czytelnictwa młodzieży. Pragnę jednak podkreślić, że zawarta w tekście sugestia prezentowania młodym ludziom dzieł hipertekstowych nie oznacza pomijania czy odrzucania literatury drukowanej, a jedynie uzupełnienia świata książek e-utworami. W narracjach tradycyjnych niepodzielnie królujących na lekcjach języka polskiego ${ }^{2}$ prze- $^{-}$ strzeń, postacie, emocje czy doświadczenia portretowane są za pomocą słów, co wymaga od odbiorcy wyobrażania sobie owych obiektów i światów. W dobie zwrotu cyfrowego taki sposób przedstawienia odbiega do preferencji typowego nastolatka, który

lgnie bezkrytycznie do tego, co wizualne. Imponuje mu (...) cywilizacja teledysków, reklam, filmów, spotów, czyli tzw. kultury masowej i przemawianie do niego wyłącznie językiem Dantego, Blake’a i Eliota początkowo na nic się zda, a wręcz przeciwnie - może jedynie od literatury odstraszyć (Strokowski 2004, 304).

Warto więc próbować zainteresować młodego człowieka utworami literackimi, pokazując mu teksty, w których autorzy - dzięki narzędziom elektronicznym - sugestywnie przedstawiają wymyśloną rzeczywistość, a tym samym ułatwiają odbiorcy (re)konstruowanie obrazów. „Czytając” multimedialne dzieło hipertekstowe, można widzieć, słyszeć, obserwować ruch, a dzięki temu odczuwać wrażenie realności, dotykalności i pełniej

\footnotetext{
1 W raporcie dotyczącym czytelnictwa w 2016 roku za ksiażki $w$ formacie cyfrowym uznano „e-booki, skany drukowanych książek, a także audiobooki” (Koryś, Kopeć, Zasacka, Chymkowski 2017, 14).

${ }^{2}$ W najnowszej podstawie programowej kształcenia polonistycznego w szkole podstawowej przyjętej 14 lutego 2017 roku w zapisach szczegółowych wśród tekstów kultury wymienia się m.in. literaturę piękną, popularnonaukową, publicystykę, obrazy, rzeźbę, fotografię, teatr, film, muzykę, pomijając w ten sposób całą sztukę Internetu (net art), w tym hipertekstową prozę i cyfrową poezję tworzoną przez polskich autorów od 2002 roku. Nie wiadomo, czy takie dzieła zostaną uwzględnione w zaleceniach ministerialnych dotyczących edukacji w szkole średniej, ponieważ w momencie powstawania niniejszego tekstu stosowne dokumenty nie zostały jeszcze zatwierdzone. Sądzę jednak, że taki scenariusz jest mało prawdopodobny.
} 
zanurzyć się w opowieść ${ }^{3}$. Tekst jest bowiem uchwycony w wielopiętrowej architekturze opartej na interesujących rozwiązaniach technicznych, znanych młodzieży z portali społecznościowych, czyli przede wszystkim na hipertekście i przełamanej linearności, połączeniu słowa $\mathrm{z}$ obrazem i dźwiękiem, wreszcie na zespoleniu typografii statycznej z kinetyczną ${ }^{4}$ (por. np. Szczęsna 2009).

W utworze elektronicznym tekst nie jest jak dotychczas ułożony w sposób ciągły i niejako w stanie surowym wlany w stałą przestrzeń kolumny. W środowisku cyfrowym zostaje on poszatkowany na fragmenty-leksje stanowiące wspomniany hipertekst wskutek ich zorganizowania $\mathrm{w}$ nielinearnej strukturze. „Porcje” opowieści często opartej - jak w książce drukowanej - na jednym głównym wątku zostają połączone siecią linków, co $\mathrm{z}$ jednej strony przypomina powiązania intertekstualne (zob. Zawojski 2010), a z drugiej warunkuje lekturę wyboru dzięki możliwości wielokierunkowego „przemierzania” dzieła. Twórca książki hipertekstowej modeluje różne ścieżki odbioru i pozostawia czytelnikowi wchodzącemu w rolę poszukującego sensu detektywa dowolność w zakresie poruszania się po utworze (Simanowski 2007, 379). Autor powieści hipertekstowej nie może więc w pełni panować nad fabułą, gdyż brak narzuconej kolejności partii tekstu zmusza odbiorcę do przyjęcia aktywnej, dionizyjskiej postawy lekturowej (Przybyszewska 2014) i wyboru jednej z zaproponowanych dróg ${ }^{5}$. Podjęcie konkretnych decyzji i wykonanie operacji w obrębie hipertekstu konstytuuje dzieło (a właściwie jego wariant). Daleko zatem takiej literaturze (podobnie jak liberaturze) do tradycyjnej poetyki kojarzonej z ładem, harmonią i uporządkowaniem. Przypomina ona raczej zarządzanie chaosem uwzględniające przypadkowość, nieokreśloność oraz rezygnację ze skończonej, stabilnej formy (Czaplejewicz 2009), co implikuje przekonanie o niemożności czy wręcz bezzasadności wykorzystania takich dzieł w praktyce edukacyjnej (por. Pawlicka 2014b). Takie utwory ze względu na wielowarstwową strukturę i elektroniczną specyfikę mogą się jednak okazać atrakcyjne dla młodego czytelnika, dla którego przestrzeń Internetu jest naturalnym miejscem codziennego funkcjonowania, uczenia się

\footnotetext{
${ }^{3}$ Niektórzy badacze podają w wątpliwość możliwość czerpania przyjemności z hipertekstu przez czytelników przyzwyczajonych do korzystania z tradycyjnych tekstów drukowanych. James Pope (2006) dowodzi jednak, że takie sądy są nieuzasadnione, gdyż nawyki lekturowe nie stanowią przeszkody w obcowaniu z nielinearnym tekstem elektronicznym. Podstawowym wyznacznikiem atrakcyjności utworu stworzonego w sieci jest natomiast jego zdaniem interesujący interfejs i zastosowane rozwiązania kompozycyjne.

${ }^{4}$ Mam świadomość istnienia głębokich różnic zachodzących między literaturą tradycyjną a hipertekstową. Przywołane w tekście sądy badaczy zajmujących się utworami sytuującymi się w pierwszym ze wskazanych obszarów nie stanowią przypadkowych nawiązań, gdyż moim zdaniem mają moc wyjaśniającą w odniesieniu do dzieł cyfrowych.

5 Aspekt ten znajduje najpełniejszy wyraz w literaturze grywalnej, w której czytelnik wciela się w bohatera i podejmuje w jego imieniu konkretne decyzje. Przykładami mogą być utrzymane w konwencji gry paragrafowej adaptacje: (1) powieść Popiół i diament Jerzego Andrzejewskiego opracowana przez Agnieszkę Słodownik, Michała Danielewicza i Michała Szotę z muzyką Kevina MacLeoda (http://popioldiament.pl/) oraz (2) opowiadania Brunona Schulza przekształcone w dzieło Bałwochwał przez Mariusza Pisarskiego i Marcina Bylaka ze ścieżką dźwiękową Artura Sosena Klimaszewskiego (http://ha.art.pl/schulzh).
} 
i obcowania z kulturą ${ }^{6}$ (np. Zasacka 2008; Mysior 2014). I co ważniejsze - stykanie się z takimi pokawałkowanymi cyber-książkami nie jest bezwartościowe, bowiem pozwala modelować rozmaite umiejętności. Co więcej, możliwość sięgania do e-opowieści w każdym miejscu i w dowolnym czasie za pośrednictwem urządzeń mobilnych może przyczynić się do wykształcenia i umocnienia nawyku obcowania z utworami literackimi, również tymi, które zostały utrwalone na papierze (Jabłoński 2012, 26) ${ }^{7}$.

Utwór hipertekstowy charakteryzuje się przede wszystkim wspomnianymi już nielinearnością i wielowarstwowością, dlatego internauta ma do wyboru trzy porządki odbioru treści: linearny (czytanie klasyczne, składanie segmentów w sposób szeregowy zgodnie z kolejnością zapisu), symultaniczny (percypowanie równocześnie różnych rodzajów znaków, np. obrazu i tekstu), linkowy/hipertekstowy/skokowy (czytanie nieciągłe polegające na przeskakiwaniu z warstwy do warstwy) (Szczęsna 2009, 70). Bez względu na sposób przyswajania tekstu, podobnie jak w przypadku obcowania z książką tradycyjną, czytelnik literatury hipertekstowej - mającej na ogół charakter fabularny - tworzy w umyśle reprezentacje świata przedstawionego, towarzyszy bohaterom w ich przygodach, rozwiązuje z nimi problemy, współodczuwa z nimi, kształtując w ten sposób swój światopogląd i własną wrażliwość. Dodatkowo hipertekst implikuje nowy poziom kreatywności (Constantinescu 2009, 97), ponieważ - jak wspomniałam - wymaga „dowolnej reorganizacji dokonującej się w indywidualnym akcie przetworzenia (...), [i] nie istnieje bez odbiorcy obdarzonego inwencją i sporą dozą wyobraźni, gotowego do podjęcia twórczej gry zaproponowanej przez autora" (Prajzner 2004, 165). Czytający otrzymuje zbiór powiązanych w gęstą sieć elementów, które zgodnie z własnymi preferencjami i interesami musi poskładać w całość niczym układankę (por. Sandbothe 2001, 217; Prajzner 2004, 154; Gołębiewski 2008, 40-42). To zadanie wymaga podjęcia nietrywialnego, intelektualnego wysiłku, gdyż odbiorca jest współodpowiedzialny za losy bohatera, które tworzy poprzez kolejno klikane hiperłącza odsyłające do jednego z wielu tekstów równoległych funkcjonujących na różnych poziomach utworu. Nielinearność i narracja synchronicznych rozgałęzień (Kudra 2006, 124), czyli - zgodnie z terminologią Espena Aarsetha (2006; 2014) dyskurs ergodyczny (gr. ergon 'praca' + hodos 'ścieżka') - umożliwia użytkownikowi konstruowanie alternatywnych opowieści ${ }^{8}$. Wymaga to natomiast skupienia na tekście, potęguje napięcie i zaciekawienie ze

\footnotetext{
${ }^{6}$ Badania czytelnictwa wykazują, że w 2016 roku „ok. 3\% co najmniej piętnastoletnich Polaków uczestniczy[ło] w kulturze książki bez pośrednictwa druku” (Koryś, Kopeć, Zasacka, Chymkowski $2017,14)$.

${ }^{7}$ Oczywiście mam świadomość trudności wprowadzania literatury hipertekstowej do edukacji szkolnej, naznaczonej rozbieżnością między koniecznością kształcenia kompetencji a konsumpcyjno-ludycznymi potrzebami uczniów (Zasacka 2014, 216). Sądzę jednak, że proces dydaktyczny nie ucierpi wskutek przeznaczenia na prezentację tej części cyfrowego piśmiennictwa jednej godziny polskiego w roku. Ponadto z powodzeniem można pokazywać młodzieży dzieła hipertekstowe podczas zajęć pozalekcyjnych.

${ }^{8}$ Oparcie tekstu na wybieralności czy fakultatywności można było dostrzec w dziełach zaliczanych do wspomnianej liberatury, które także mogą stanowić czynnik zachęcający młodzież do sięgania po książki.
} 
względu na tajemnicę, jaką kryją zaproponowane przez autora linki. I o ile istnieje ryzyko zagubienia się $\mathrm{w}$ lekturze i powierzchownego dekodowania, co znamionuje również czytanie dzieł drukowanych, o tyle pokusa quasi-budowania narracji zachęca do odkrywania przygotowanych przez twórcę warstw tekstu. Zaoferowana „odbiorcy pula możliwych działań jest (...) [bowiem] wystarczająca do tego, by wytworzyć w nim wiarę, iż to on sam jest autorem zdarzającego się opowiadania istniejącego $\mathrm{w}$ wielu wersjach, funkcjonującego jako zdarzenie każdorazowo przez niego projektowane" (Szczęsna 2007, 154).

Wyzwolenie tekstu ze sztywnych ram kartki, dekonstrukcja opowieści w leksje i jej reorganizacja w segmenty powiązane linkami mającymi moc kojarzenia, zmieniania, redefiniowania (por. Schneider, Foot 2008, 27) dostarczają czytelnikowi - podobnie jak w przypadku narracji linearnych - wielu niedookreślonych elementów, które zgodnie z koncepcją dzieła otwartego trzeba samodzielnie wypełnić (Eco 1994, 6 i n.). To oznacza, że korzystanie z literatury hipertekstowej może kształcić kompetencje interpretacyjne. Ułożenie fabuły w piętrową, nielinearną strukturę warunkuje wręcz paninterpretacjonizm, ponieważ odbiorca nie tylko wypełnia pozostawione przez twórce „puste” miejsca asocjacjami i wyobrażeniami wynikającymi m.in. z jego wiedzy, światopoglądu, doświadczeń, usposobienia. Wielość konkretyzacji szablonu i - w efekcie - mnogość odczytań warunkuje dodatkowo samodzielne decydowanie o kolejności otwieranych porcji tekstu, a zatem konstruowanie tekstu z dostępnych elementów. Innymi słowy, zetknięcie z hipertekstową opowieścią jest refleksyjne, bliskie tradycyjnemu sposobowi czytania, przy czym wraz z postępem lektury operacje interpretacyjne stają się coraz intensywniejsze i wielopoziomowe (Kudra 2006, 120; Cieślikowski 1985). Kontakty z cyfrowym dziełem mogą się zatem okazać prawdziwie ciekawe, bowiem nastolatek nie musi rekonstruować tego, co autor miał na myśli ${ }^{9}$. Hipertekst wszak „nie tylko zamienił, ale wprost zniszczył jednoznaczność wymiany informacji. Stworzył nową narrację (...) bez określonego początku i końca" (Kudra 2007, 298), sprzyjającą wolności interpretacyjnej. W akcie lektury często nie aktualizuje się przecież całość zaproponowanej przez autora kompozycji, ponieważ użytkownik podąża zaprojektowanymi ścieżkami w dowolnym porządku bez konieczności sprawdzania wszystkich dostępnych łączy (Pisarski 2011, 187). Niekliknięte warstwy pozostają w chmurze, funkcjonując na zasadzie fikcji potencjalnej. Taka kompozycja otwiera więc bramę do autentycznej dyskusji o utworze, ponieważ wymyka on się jednoznacznym rozstrzygnięciom. Poszczególne dzieła hipertekstowe nie zostały jeszcze

9 Literaturoznawcy, dydaktycy i nauczyciele dowodzą natomiast, że zniechęcenie do czytania uwarunkowane jest często instrumentalnym traktowaniem książki sprowadzającym się do odszukania konkretnych informacji. Dodatkowymi czynnikami są drobiazgowa kontrola znajomości treści (sprowadzająca się do pytań chociażby o kolor sukienki czy imię bohatera lub zwierzęcia pojawiającego się okazjonalnie w utworze), lekceważenie uczniowskich odczuć lekturowych oraz pozbawianie młodzieży prawa do własnej interpretacji (por. m.in. Uryga 1996; Janus-Sitarz 2003; 2009). 
zamknięte w konkretnych teoretyczno-analitycznych ramach, co pozwala na swobodne, indywidualne (umotywowane) osądy (Janus-Sitarz 2012, 77; Koziołek 2014, 198-199). Czytający mogą więc wymieniać własne poglądy i formułować rozmaite interpretacje, nawet skrajnie odbiegające od spostrzeżeń polonisty, a co istotne, żadne z tych opinii nie będą lepsze czy gorsze. Obcowanie $\mathrm{z}$ hipertekstem jawi się jako wyzwanie sprzyjające prawdziwemu (a nie sterowanemu) odkrywaniu i przeżywaniu. Młody człowiek - jak krytyk - „zaczyna od percepcji, angażuje swoją wrażliwość, aktywizuje (...) inne doświadczenia artystyczne, (...) analizuje swoje reakcje (...) i [musi] połączyć tak zaktywizowany system wrażeń z własną »wyobraźnią językową " (Juszczak 1972, 41).

Tworzenie utworu literackiego w sieci przypomina konstruowanie instalacji z różnych elementów, przy czym autor nie skupia się na transparentnej prezentacji tekstu, a kładzie szczególny nacisk na atrakcyjność rozwiązań estetycznych (Bierkowski 2008, 59). Wyzwolenie z tradycyjnych konwencji typograficznych stoi bowiem pod znakiem „geometrii kompozycji i trygonometrii semantyki” (Nowakowski [b.d.w.]), czyli uprzestrzennienia struktury i współfunkcjonowania w dziele składników językowych i niejęzykowych. Utwór hipertekstowy jest warstwowy i polisemiotyczny, gdyż obok tekstu - jak nadmieniłam - wykorzystywane są obraz, dźwięk, ruch. Ze znakami współgrają barwy, litery układają się w kaligramy (np. w Liberlandii Radosława Nowakowskiego) i jak w typografii kinetycznej przemieszczają się na ekranie, pojawiają się i zanikają (jak w wykonanej przez Urszulę Pawlicką cyfrowej adaptacji Sensacji w kinie Tytusa Czyżewskiego). Dzięki takim zabiegom autorowi łatwiej przedstawić zdarzenia dziejące się w tym samym czasie, oddać kolorem lub fonią nastrój sceny, budować napięcie, sugestywnie zilustrować bohaterów czy przedstawić sposób postrzegania i odczuwania danej sytuacji przez różne istoty (np. w zespołowo tworzonej powieści Piksel Zdrój), uzmysławiając na przykład, że perspektywy artysty, dziecka, wieśniaka, „latającego nad wsią jastrzębia i biegającej koło ganku myszy znacznie się od siebie różnią" (Dawidek-Gryglicka 2011). Radosław Nowakowski twierdzi nawet, że dopiero takie rozwiązania techniczne (wykorzystane przez niego w hipertekstowej powieści Koniec świata według Emeryka) pozwalają adekwatnie przedstawić fabułę, bowiem „żadna opowieść nie jest prostym, wybrukowanym traktem - każda jest poplątaną, nieustannie rozgałęziającą się ścieżką biegnącą na różnych poziomach, przez rozmaite warstwy, płaszczyzny, tła” (Marecki 2005). Tak misternie skonstruowany, heterogeniczny utwór jest efektowny i może silnie interesować czytelnika, zwłaszcza młodego, który czasem postrzega śledzenie rządków pisma utrwalonych na papierze jako monotonne i nużące zajęcie.

Literatura hipertekstowa za sprawą polisemiotyczności, wielowarstwowości, szukania sensu, komponowania całości z dostępnych elementów może być nie tylko „intelektualnie kontemplowana, ale staje 
się prawdziwą frajdą, którą przeżywa się całym sobą i która powoduje wypieki na twarzy, (...) prawdziwe i intensywne emocje" (Dziok 2009, 43), co potwierdza chociażby przykład kolaboratywnej powieści Piksel Zdrój funkcjonującej w sieci od 2015 roku. W tym utworze jednym z wątków fabularnych jest zagadka kryminalna, którą musi rozwikłać sam czytelnik, ponieważ autorzy nie podają mu - jak to zwykle bywa w narracjach tradycyjnych - gotowego rozwiązania. W celu realizacji tego zadania trzeba więc zgromadzić informacje, przemierzając hipertekstowy labirynt składający się z 16 opowieści poszatkowanych na niemal 250 segmentów zawierających porcje tekstu, obrazy, ścieżki audialne i audiowizualne, przy czym leksje te połączono ze sobą ponad 1300 linkami. Odbiorca samodzielnie decyduje, czyje - kolorystycznie zdywersyfikowane - relacje będzie poznawał - Olafa, Klemensa, Lukrecji czy też pięciu innych bohaterów opisujących to samo zdarzenie z własnej perspektywy, typowym dla siebie stylem. Z kolei umieszczony w graficznym interfejsie stale widoczny "trójkąt fabularny" informujący czytelnika o postępie w rozwiązywaniu detektywistycznej łamigłówki ([Techsty] 2015) wzmaga zarówno zaciekawienie, jak i wytrwałość w poszukiwaniu wskazówek w kolejnych warstwach hipertekstu. Omawiany utwór prowokuje do konstruowania opowieści oraz nieustannej interpretacji tworzonej fabuły i mógłby stanowić dla młodzieży punkt wyjścia do dzielenia się wrażeniami, doświadczeniami, osiągnięciami, a nawet do połączenia wysiłków w rozwikływaniu tajemnicy. Co więcej, dzieło mogłoby pełnić w szkole podstawowej funkcję intrygującego kontekstu na lekcji języka polskiego poświęconej wybranej przez nauczyciela powieści Agaty Christie ${ }^{10}$, stwarzającym pole do dyskusji na temat przemian prozy kryminalnej.

Trzeba także nadmienić, że niekonwencjonalność i polifoniczność utworu hipertekstowego potęguje dodatkowo jego nieskończoność i niestabilność, ponieważ autor już po jego udostępnieniu może w dowolnej chwili zmieniać fragmenty, dodać nowe leksje czy też powiązać istniejące warstwy innymi niż dotychczas ścieżkami. Dzieło jest zatem w nieustannym ruchu, często posiadając w swej strukturze linki prowadzące donikąd albo do miejsc, z którymi odbiorca już się zapoznał (jak w powieści Hegiroskop Stuarta Moulthropa w przekładzie Mariusza Pisarskiego). Przekształcanie dokonujące się na oczach czytelnika umożliwia śledzenie procesu twórczego skutkującego rodzeniem się książki, a tym samym realizację jednego z podstawowych zadań polonistyki (np. Biernacka 2004, 284 i n.) - pozwala kształcić kreatywność i pomysłowość młodego człowieka. Nastolatek może podpatrywać różne techniki konstruowania opowieści i hipertekstu, wiązania elementów czy projektowania warstw, a tym samym generować własne skojarzenia i pomysły literacko-architektoniczne, które zdoła

10 Zgodnie z podstawą programową, która weszła w życie 1 września 2017 roku, wśród lektur uzupełniających dla w klas VII-VIII szkoły podstawowej znalazła się właśnie wybrana powieść wspomnianej autorki. 
samodzielnie zmaterializować na dostępnych obecnie portalach oferujących możliwość bezpłatnego projektowania stron internetowych (zarówno witryny anglojęzyczne wix.com, jigsy.com, doodlekit.com czy imcreator. com, jak i posiadające polskie menu webwavecms.com lub weebly.com). I sądzę, że takie tworzenie książki, której strukturę można rozpisać w formie mapy mentalnej, może się jawić cyfrowym tubylcom jako wciągające, literacko-informatyczne zadanie, znacznie ciekawsze niż kreślenie na kartce uszeregowanych wyrazów ${ }^{11}$.

Kształcenie umiejętności obcowania z tekstami kultury w okresie młodzieńczym ma niewątpliwie fundamentalne znaczenie dla rozwijania horyzontów. Literatura (i nie tylko) oddziałuje wszak na czytelnika, pozwala odkryć „głębię, zmusza do przemyśleń, refleksji nad własnym życiem. (...) może więc służyć jako najdoskonalsze źródło wiedzy użytecznej zarówno w codziennym działaniu, samokształceniu, jak i kształtowaniu postaw, a więc wpływać na rozwój całej osobowości człowieka” (Kopeć 2002, 192). Z tego też względu nastolatek powinien z pomocą nauczyciela (i rodziców) odkryć pasjonujące dzieła dostosowane do jego upodobań oraz potrzeb poznawczo-emocjonalnych. Sądzę, że powyższe rozważania dowodzą zasadności upatrywania $\mathrm{w}$ literaturze cyfrowej nowoczesnego narzędzia rozwijania zainteresowań czytelniczych młodzieży, co z kolei przemawiałoby za wykorzystaniem tych utworów w edukacji polonistycznej. Taki postulat może być oczywiście kontrowersyjny, ponieważ część literaturoznawców nie oceniłaby pozytywnie dzieł hipertekstowych ze względu na z jednej strony fragmentaryczność i palimpsestowość, z drugiej - poetykę chaosu i banału. W dodatku książki skonstruowane w sieci cechują wszystkie właściwości, które odstraszają polonistów od utworów współczesnych. Chodzi tu przede wszystkim o odchodzenie od fabularności, skupienie na formie, eksperymentach kompozycyjno-wizualnych i operowanie obfitującym w wulgaryzmy językiem wywołującym w nauczycielach niemałą konsternację (Janus-Sitarz 2012, 77-78). Książki hipertekstowe mogą jednak idealnie trafić w gusta współczesnej młodzieży (np. Jabłoński 2012) ze względu na funkcjonowanie w przestrzeni cyfrowej oraz ponętność hybrydalnej struktury. Połączenie słowa z obrazem, dźwiękiem, animacją, gra barw, kształtów i warstw gwarantuje swoistą literacko-rozrywkową ucztę, a przy tym intelektualno-twórczą inspirację. Czytelnik e-opowieści „to gracz, hazardzista, a cybertekst to gra-świat; można tu wędrować i błądzić, [nieustannie] odkrywać tajne ścieżki w tekście” (Aarseth 2006, [b.p.]; por. Huizinga 2007, 20 i n.). Obcowanie z taką nielinearną opowieścią-układanką wciąż rozwija zdolność czytania ze zrozumieniem, wrażliwość estetyczną oraz inne kompetencje ujmowane od lat w podstawach programowych języka polskiego w zakresie

${ }^{11}$ Realizacja takiego zadania może wymagać pomocy polonisty i informatyka, którzy winni służyć radą. Co więcej, stworzenie przez ucznia takiego dzieła należałoby nagrodzić pochwałą, oceną, a także promocją na terenie szkoły i poza nią; może to motywować do twórczości innych młodych ludzi (por. Biernacka 2004). 
kształcenia literacko-kulturowego ${ }^{12}$. Opowiadanie o dziele hipertekstowym i zawartej w nim fabule wymaga bowiem z jednej strony skupienia na tekście, wiązania poszczególnych składników w większe całości, wydobycia wątków głównych i pobocznych, zidentyfikowania bohaterów pierwszoi drugoplanowych, dostrzeżenia globalnego sensu utworu, sformułowania własnej interpretacji i jej uargumentowania, a z drugiej - odwołania do wiedzy z zakresu teorii literatury, poetyki, ale też informatyki i plastyki ze względu na połączenie warstwy narracyjnej z interesującymi elementami graficzno-wizualnymi komplikującymi znacznie warstwę estetyczną. Młody człowiek, podobnie jak podczas czytania książki tradycyjnej, może wyobrażać sobie świat przedstawiony, opisywać skonstruowane przez autora postacie, ustalać kolejność wydarzeń ${ }^{13}$, poszukiwać w tekście typowych środków stylistycznych (porównania, epitety, animizacje, personifikacje, hiperbole, oksymorony, parafrazy, paronomazje itd.), angażować się w losy bohaterów, oceniać ich postępowanie, analizować podjęte decyzje, a także poszukiwać kontekstów kulturowych, filozoficznych, historycznych, biograficznych itd. Doskonali więc umiejętność logicznego myślenia, analizy, syntezy, selekcji informacji, opowiadania o utworze i wyrażania własnych opinii, rozwijając przy tym inteligencję racjonalną i emocjonalną oraz pamięć epizodyczną, semantyczną, proceduralną i skojarzeniową (por. Budrewicz 2012).

Odwołując się do koncepcji Marii Pruszkowskiej, która w powieści Przyślę Panu list i klucz wyróżniła trzy rodzaje książek: (1) te, które się czyta, (2) te, które się pochłania i (3) te, które pochłaniają czytelnika, dzieła hipertekstowe zdecydowanie należy umieścić w tej trzeciej kategorii. Dotychczas młody odbiorca musiał śledzić historię podaną przez autora w uszeregowanych słowach (Federman 1983, 426). Dzięki dobrodziejstwu techniki posiadł niedostępną do tej pory możliwość decydowania o kierunku rozwoju narracji, dzięki czemu może - jak powiedziałby Barthes $(1999,38)$ - „W pełni zachwycać się grą significants i rozkoszować (...) nieograniczoną wolnością przyjmowania lub odrzucania tekstu”. Z kolei sposobność przemierzania utworu różnymi drogami, wielopiętrowość opowieści, zapętlenia, ruchome ramy kompozycyjne powodują, że żadna interpretacja nie jest ostateczna i stabilna, a wskutek stałego zaciekawienia i tajemnicy przyjemność kontaktu z dziełem nigdy nie traci na sile. Pokazanie takich książek młodemu człowiekowi dokonującemu fundamentalnych wyborów kulturowych, przedstawicielowi pokolenia Z permanentnie eksploatującemu nowoczesne technologie, pozwoli więc ujrzeć nowe, fascynujące oblicze literatury.

${ }^{12} \mathrm{Na}$ przestrzeni tekstu można byłoby z łatwością umieścić odwołania do konkretnych zapisów z najnowszej podstawy programowej. Z uwagi jednak na to, że dotychczas (maj 2017 rok) sprecyzowano zalecenia ministerialne tylko dla szkół podstawowych (a wcześniejsze dokumenty uchylono), zrezygnowałam z systemu oznaczeń, gdyż mogłoby to sugerować, że niniejszy tekst dotyczy wyłącznie rozwijania kompetencji najmłodszych czytelników.

13 Świetnie w realizacji tego zadania sprawdzą się bezpłatne programy online służące tworzeniu mapy myśli, np. bubble.us czy iMindMap.pl. 


\section{Bibliografia}

Aarseth Espen J., 2006, Cybertekst. Perspektywy literatury ergodycznej, Sikora D., Pisarski M. (przeł.), „Techsty”, nr 2, http://www.techsty.art.pl/magazyn2/ artykuly/aarseth_cybertekst.html (dostęp 2.04.2017).

Aarseth Espen J., 2014, Cybertekst. Spojrzenia na literaturę ergodyczna, Pisarski M. (przeł.), Kraków-Bydgoszcz.

Barthes Roland, 1999, S/Z, Markowski M.P., Gołębiewska M. (przeł.), Warszawa. Bierkowski Tomasz, 2008, O typografii, Gdańsk.

Biernacka Anna, 2004, Szkoła i polonistyka w społeczeństwie informacyjnym, w: Janus-Sitarz A. (red.), Polonista w szkole. Podstawy kształcenia nauczyciela polonisty, Kraków, s. 275-296.

Budrewicz Zofia, 2012, Odbiorca szkolnej lektury jako podmiot doświadczajacy, w: Biedrzycki K., Janus-Sitarz A. (red.), Doświadczenie lektury. Między krytyka literacka a dydaktyka literatury, Kraków, s. 63-73.

Burzyńska Anna, 2012, Doświadczenie lektury, w: Biedrzycki K., Janus-Sitarz A. (red.). Doświadczenie lektury. Między krytyka literacka a dydaktyka literatury, Kraków, s. 9-29.

Cieślikowski Jerzy, 1985, Literatura osobna, Warszawa.

Constantinescu Cătălin, 2009, The validity of reader-oriented criticism in electronic media, „Philologica Jassyensia”, nr 1(9), s. 95-101.

Czaplejewicz Eugeniusz, 2009, Artyzm i chaos. Z pogranicza poetyki i estetyki, w: Ulicka D. (red.), Tekst (w) sieci, t. 1: Tekst - Język - Gatunki, Warszawa, s. 49-58.

Dawidek-Gryglicka Małgorzata, 2011, Emeryk jako cybertekst, czyli o powieści Radosława Nowakowskiego raz jeszcze, „Techsty”, nr 7, http://techsty.art.pl/ magazyn/magazyn7/artykuly/gryglicka01.html (dostęp 2.04.2017).

Dziok Anna, 2009, Literatura hipertekstowa w świetle estetycznej kategorii zaangażowania, w: Kubicka H., Taranek O. (red.), Kody kultury. Interakcja, transformacja, synergia, Wrocław, s. 41-49.

Eco Umberto, 1994, Dzieło otwarte. Forma i nieokreśloność w poetykach współczesnych, Gałuszka J. (przeł.), Warszawa.

Federman Raymond, 1983, Surfikcja - cztery propozycje $w$ formie wstępu, w: Lewicki Z. (oprac.), Nowa proza amerykańska. Szkice krytyczne, Warszawa, s. 421-432.

Gajda Stanisław, 2000, Media - stylowy tygiel współczesnej polszczyzny, w: Bralczyk J., Mosiołek-Kłosińska K. (red.), Język $w$ mediach masowych, Warszawa, s. 19-27.

Gołębiewski Łukasz, 2008, Śmierć książki. No future book, Warszawa.

Huizinga Johan, 2007, Homo ludens. Zabawa jako źródło kultury, Kurecka M., Wirpsza W. (przeł.), Warszawa.

Hayles N. Katherine, 2007, Electronic Literature. What is it?, „Electronic Literature Organisation", vol. 1, https://eliterature.org/pad/elp.html\#sec3 (dostęp 9.12.2017). 
Jabłoński Artur, 2012, Literatura hipertekstualna w szkole, „Polonistyka”, nr 4, s. 24-27.

Janus-Sitarz Anna, 2003, Uczyć dla lektury, „Polonistyka”, nr 10, s. 33-38.

Janus-Sitarz Anna, 2009, Przyjemność i odpowiedzialność w lekturze. O praktykach czytania literatury w szkole. Kontestacje, oceny, propozycje, Kraków.

Janus-Sitarz Anna, 2012, Nauczyciel w roli krytyka literackiego, w: Biedrzycki K., Janus-Sitarz A. (red.), Doświadczenie lektury. Między krytyka literacka a dydaktyka literatury, Kraków, s. 74-84.

Juszczak Wiesław, 1972, Dwie krytyki: „krytyczna” i „komentujaca”, „Teksty. Teoria literatury, krytyka, interpretacja", nr 4, s. 38-55.

Kopeć Urszula, 2002, Kształcenie umiejętności czytania w szkole podstawowej, w: Kurczab H., Kopeć U., Kozłowska E. (red.), Wybrane zagadnienia edukacji polonistycznej, Rzeszów, s. 191-199.

Koryś Izabela, Kopeć Jarosław, Zasacka Zofia, Chymkowski Roman, 2017, Stan czytelnictwa w Polsce w 2016 roku [raport], Warszawa, http://www.bn.org. pl/download/document/1492689764.pdf (dostęp 8.12.2017).

Koziołek Krystyna, 2014, Dydaktyka regresywna, czyli czego trzeba się oduczyć, żeby uczyć lektury, w: Biedrzycki K., Bobiński W., Janus-Sitarz A., Przybylska R. (red.), Polonistyka dziś - kształcenie dla jutra, t. 2, Kraków, s. 195-203.

Kudra Andrzej, 2006, Hiperjęzyk hipertekstu a chiralność, „Media - Kultura Społeczeństwo", nr 1, s. 119-127.

Kudra Andrzej, 2007, (Nie)moja mimesis, „Acta Universitatis Lodziensis. Folia Litteraria Polonica”, nr 9, s. 293-300.

Marecki Piotr, 2002, Liternet.pl, w: Marecki P. (red.), Liternet. Literatura i Internet, Kraków.

Marecki Piotr, 2005, Rashomon do potęgi entej [wywiad z Radosławem Nowakowskim], http://ksiazki.onet.pl/rashomon-do-potegi-entej/fp7sj (dostęp 2.04.2017).

Michalak Dominika, Koryś Izabela, Kopeć Jarosław, 2016, Stan czytelnictwa w Polsce w 2015 roku [raport], Warszawa, http://www.bn.org.pl/download/ document/1459845698.pdf (dostęp 15.04.2017).

Mysior Radosław, 2014, Dwa światy - cyfrowi tubylcy, cyfrowi imigranci. Cz. 1, „Remedium”, nr 9, s. 5-7.

Nowakowski Radosław, [b.d.w.]. HASA RAPASA: opis spektaklu niemożliwego, http://www.liberatorium.com/hasa/rapasa.html (dostęp 2.04.2017).

Osiecka-Chojnacka Justyna, 2014, Czytelnictwo $w$ Polsce i innych państwach Unii Europejskiej, „Infos. Zagadnienia społeczno-gospodarcze”, nr 17 (177), http://orka.sejm.gov.pl/WydBAS.nsf/0/0291AD9C4904205EC1257D62004108A1/\$file/Infos_177.pdf (dostęp 28.03.2017).

Papuzińska Joanna, 1981, Inicjacje literackie. Problemy kontaktów dziecka $z$ książka, Warszawa.

Pawlicka Urszula, 2014a, Literatura elektroniczna. Stan badań w Polsce, „Teksty Drugie", nr 3, s. $141-161$. 
Pawlicka Urszula, 2014b, Nauczanie literatury cyfrowej. Trochę wątpliwości i o wiele więcej zysków, w: Biedrzycki K., Bobiński W., Janus-Sitarz A., Przybylska R. (red.), Polonistyka dziś - kształcenie dla jutra, t. 2, Kraków, s. 60-81.

Pisarski Mariusz, 2011, Hipertekst a intertekstualność: powinowactwa i rozbieżności, „Porównania”, nr 8, s. 183-193.

Pope James, 2008, A Future for Hypertext Fiction, „Convergence: The International Journal of Research into New Media Technologies", nr 12 (4), s. 447-465.

Prajzner Katarzyna, 2004, Postmodernism Comes True? Kilka uwag na marginesie teorii hipertekstu, „Kultura Współczesna”, nr 1(39), s. 153-171.

Przybyszewska Agnieszka, 2014, Ku literaturze grywalnej (kilka uwag wstępnych), „Przegląd Kulturoznawczy”, nr 2, s. 127-147.

Sandbothe Mike, 2001, Transwersalne światy medialne. Filozoficzne rozważania o Internecie, Krzemieniowa K. (przeł.), w: Gwódź A. (red.), Widzieć, myśleć, być. Technologie mediów, Kraków, s. 205-231.

Schneider Steven M., Foot Kirsten A., 2008, Sieć WWW jako przedmiot badań naukowych, w: Dytman-Stasieńki A., Stasieńko J. (red.), WWW - w sieci metafor. Strona internetowa jako przedmiot badań naukowych, Wrocław, s. 23-33.

Simanowski Roberto, 2007, Hipertekst. Znamiona, badania, poetyka, Roszak J. (przeł.), „Przestrzenie Teorii”, nr 7, s. 369-381.

Strokowski Wojciech, 2004, Polonista polimedialny, w: Janus-Sitarz A. (red.), Polonista $w$ szkole. Podstawy kształcenia nauczyciela polonisty, Kraków, s. 297-335.

Szczęsna Ewa, 2007, Poetyka mediów. Polisemiotyczność, digitalizacja, reklama, Warszawa.

Szczęsna Ewa, 2009, Wprowadzenie do poetyki tekstu sieciowego, w: Ulicka D. (red.), Tekst (w) sieci, t. 1: Tekst - Język - Gatunki, Warszawa, s. 67-76.

[Techsty], 2015, Piksel Zdrój. Nowa powieść hipertekstowa, http://techsty.art.pl/ aktualnosci/2015/piksel-zdroj.html (dostęp 9.12.2017).

Uryga Zenon, 1996, Sytuacje komunikacyjne szkolnej lektury, w: Godziny polskiego. Z zagadnień kształcenia literackiego, Kraków, s. 59-80.

Wolff Katarzyna, 2008, Współczesny czytelnik - między mediatyzacja a indywidualizacją. Kilka refleksji o wspólnocie narracji lekturowych i ich głównych mechanizmach, w: Żbikowska-Migoń A. (red.), Czytanie, czytelnictwo, czytelnik, Wrocław.

Zasacka Zofia, 2008, Nastoletni czytelnicy - wspólnota symboliczna i społeczne dystanse, w: Żbikowska-Migoń A. (red.), Czytanie, czytelnictwo, czytelnik, Wrocław, s. 159-174.

Zasacka Zofia, 2014, Lektury szkolne i pozaszkolne - ciagłość i zmiany w postawach czytelniczych gimnazjalistów, w: Biedrzycki K., Bobiński W., Janus-Sitarz A., Przybylska R. (red.), Polonistyka dziś - kształcenie dla jutra, t. 2, Kraków, s. 214-225.

Zawojski Piotr, 2010, Cyberkultura. Syntopia sztuki, nauki i technologii, Warszawa. 


\section{O Autorce:}

Beata Jarosz - dr, adiunkt w Zakładzie Edukacji Polonistycznej i Innowacji Dydaktycznych w Instytucie Filologii Polskiej Uniwersytetu Marii Curie-Skłodowskiej w Lublinie. Autorka jednej monografii i 40 artykułów opublikowanych $\mathrm{w}$ tomach zbiorowych oraz czasopismach (np. w „Poradniku Językowym”, „Socjolingwistyce”, „Slavice”, „Rocznikach Humanistycznych”, „Pracach Językoznawczych”, „Białostockim Archiwum Językowym”, „Z Teorii i Praktyki Dydaktycznej Języka Polskiego”). Zainteresowania naukowe: socjolingwistyka, etnolingwistyka, genologia lingwistyczna, medioznawstwo, edytorstwo, dydaktyka szkolna i uniwersytecka. 